\title{
Two new species of Melitoma Lepeletier and Serville (Hymenoptera, Apidae, Emphorini) from South America, with modified hind legs in the males
}

\author{
Arturo ROIG ALSINA \\ Museo Argentino de Ciencias Naturales «Bernardino Rivadavia,» Av. Angel Gallardo 470, \\ 1405 Buenos Aires, Argentina
}

\begin{abstract}
Two new species of Melitoma Lepeletier and Serville are described: M. fulviscopis n. sp. from Matto Grosso, Brazil, and M. torquata n. sp. from southeastern and southern Brazil, and northern Argentina. The males have a peculiar hind basitarsus, unique among emphorine bees, that suggests a close relationship of the two species. The basitarsus bears, on the inner surface, a longitudinal channel-like polished depression fringed with long hairs.
\end{abstract}

Key words: Bees, Emphorini, Brazil, Argentina.

Resumen: Dos nuevas especies de Melitoma Lepeletier y Serville de América del Sur (Hymenoptera, Apidae, Emphorini) con patas posteriores de los machos modificadas. Se describen dos nuevas especies de Melitoma Lepeletier y Serville: M. fulviscopis n. sp. de Matto Grosso, Brasil, y M. torquata n. sp. del sudeste y sur de Brasil, y norte de la Argentina. Los machos presentan un particular basitarso posterior, único entre las abejas emphorinas, que sugiere un estrecho parentesco entre ambas especies. El basitarso tiene en la cara interna una depresión lisa en forma de canal longitudinal, bordeada de largos pelos.

Palabras clave: Abejas, Emphorini, Brasil, Argentina.

\section{INTRODUCTION}

The genus Melitoma Lepeletier and Serville is a member of the Emphorini, a tribe of bees exclusive of the Americas (Michener, 2007). Its species occur from central United States of America to northern Patagonia in Argentina, but most of its diversity occurs in tropical and subtropical areas. It is characterized by the long mouthparts, the tip of the resting proboscis reaching or surpassing the mid coxae. The genus is also characterized by the elongate first flagellomere of the antenna, the subquadrate labrum, the femur of the male, which is keeled on the inner lower margin, and by the median tuft of dense hairs of the prepygidial fimbria of the female (Roig Alsina, 1999; Michener, 2007).

Species of Melitoma are specialized collectors of pollen of Convolvulaceae (Linsley et al., 1980; Bullock et al., 1991). These solitary bees usually burrow their nests on earthen banks, frequently constructing a typical turret made of mud pellets at the entrance of the nest (Linsley et al., 1980).

The genus is morphologically homogeneous, and many of its species are difficult to recognize.
The two new species here described are distinctive because of their color pattern and the modified hind basitarsi of the males. They belong in the Melitoma segmentaria species group, from which they depart in the pattern of the vestiture, but each species in a different manner. One of them is extensively black with contrasting white hairs on the head and the anterior part of the thorax. The other one, although having a pale banded metasoma, has abundant fulvous vestiture, including the scopal hairs on the hind tibia and basitarsus of the female; all other species of Melitoma have dark brown to black scopal hairs. In both species the hind basitarsus of the male bears a longitudinal channel-like polished depression on the inner surface, fringed with long hairs. This feature, not present in any other emphorine bee, suggests a close relationship of the two species.

One species is only known from Matto Grosso, Brazil. The other one follows an interesting pattern of distribution, described by Silveira \& Cure (1993), occurring in the mountainous areas of southeastern Brazil, in the highlands of the state of Paraná in Brazil, and in the lowlands in the province of Misiones, Argentina. 


\section{MATERIALS AND METHODS}

Terminology for structures follows Michener (2007). The maximum diameter of the median ocellus (MOD) is used as a reference to express the length of the pubescence and structures. In the descriptions, the metasomal terga (T) and sterna (S) are identified with Arabic numerals.

The studied specimens are deposited in the following institutions: Museo Argentino de Ciencias Naturales «Bernardino Rivadavia,» Buenos Aires (MACN); Museo de La Plata, La Plata (MLP); Museu de Zoologia da Universidade de São Paulo, São Paulo (MSP); Universidade Federal de Minas Gerais, Departamento de Zoologia, Belo Horizonte (UFMG); Universidade Federal do Paraná, Departamento de Zoologia, Curitiba (DZUP); University of Kansas, Division of Entomology (KU). Acronyms are used to indicate depositories of the specimens.

\section{Melitoma torquata Roig Alsina, new species} (Fig. 1)

Melitoma sp. Michener \& Lange, 1958: 79-81, fig. 11 (nest structure).

Diagnosis. This species is distinguished among other species of Melitoma by the extensive black vestiture of the body, except for a white collar on the anterior part of the mesosoma and the hairs on the head, which are also white. It is also distinguished by the gibbous scutellum of both sexes. The male has a strongly modified hind basitasus, which is broadened basally and bears a longitudinal glabrous channel-like depression on the inner surface. The sixth metasomal sternum of the male is unique, bearing apically a dense tuft of hairs resembling a hook.

Description. Holotype male. Length 11.5 $\mathrm{mm}$ (paratypes, 11.0-13.5 $\mathrm{mm}$ ); length of forewing $9.6 \mathrm{~mm}$ (paratypes, 9.3-10.8 mm). Color. Black, except middle of mandible and most of legs dark reddish-brown. Membrane of wings slightly infuscate, with apex beyond closed cells darker; pterostigma and veins dark brown to black.

Pubescence. White on head, pronotum, and anterior two thirds of scutum, black on rest of body; extent of white variable in the paratypes, see below. Vestiture of head and thorax dense, hairs on center of scutum 1.6-2.1 times MOD, hairs on mesopleuron longer, 1.8-2.3 times MOD. Metapostnotum with median longitudinal area devoid of hairs, laterally with erect hairs $0.4-0.9$ times MOD. Metasomal terga with sparse, appressed, short hairs, those on disc of T2 0.15-
0.3 times MOD; terga without apical hair bands. Hairs on metasomal sterna S2-S5 short, not forming apical fringes. S6 with preapical dense tuft of long, curved hairs, resembling a hook.

Sculpture. Labrum with dense, regularly distributed punctures. Clypeus with apical impunctate rim, on lower fourth with punctures dense, 0.2 diameters apart, punctures on disc sparser, 0.5-1.0 diameters apart; interspaces shiny; epistomal suture indistinct between antennal sockets, but upper margin of clypeus recognizable due to dense punctation of supraclypeal area. Scutum with punctures coalescent on area of white hairs, sparser posteriorly, with interspaces weakly tessellate; punctures on center of scutum 0.5-1.0 diameters apart. Scutellum with median gibbous elevation; anterior margin and summit of elevation polished, without punctures, laterally punctures dense, 0.2-0.5 diameters apart. Metapostnotum tessellate. Metasomal terga finely punctured.

Structure. Inner orbits nearly parallel, upper to lower interocular distance 1:1. Ocellocular and interocellar distances equal. Distance from upper margin of midocellus to summit of head in frontal view 2.1 times MOD. Labrum rectangular, 1.27 times as wide as median length. Interantennal distance 2.8 times antennocular distance. First flagellomere 2.7 times longer than its apical width; proportion of lengths of scape, pedicel and proximal three flagellomeres 1.1:0.35:1:0.35:0.32. Outer and inner hind tibial spurs sinuous. Hind basitarsus broadened basally; inner surface with a longitudinal glabrous channel-like depression bordered dorsally by row of stiff setae tilted over lumen of channel, and ventrally by series of stout, long setae.

Female. Length $13.0 \mathrm{~mm}$. Callow specimen with wings not distended. Color, pubescence and sculpture similar to those of male, except as follows. Hairs on head and thorax shorter, those on scutum 1.1-1.6 times MOD, on mesopleuron 1.51.9 times MOD. Hairs on outer surface of hind tibia 2-3 times MOD, with short retrorse barbs. Disc of clypeus more irregularly and sparsely punctate, with punctures 0.5-1.5 diameters apart; interspaces weakly tessellate. As in male scutellum with median gibbous elevation.

Structure. Inner orbits slightly sinuous, upper to lower interocular distance 1:1. Labrum rectangular, 1.3 times as wide as median length. Interantennal distance 3.5 times antennocular distance. Second segment of elongate labial palp 2.2 times as long as maximum eye length. First flagellomere 2.4 times longer than its apical width; proportion of lengths of scape, pedicel and proximal three flagellomeres 1.35:0.35:1:0.27:0.32. 

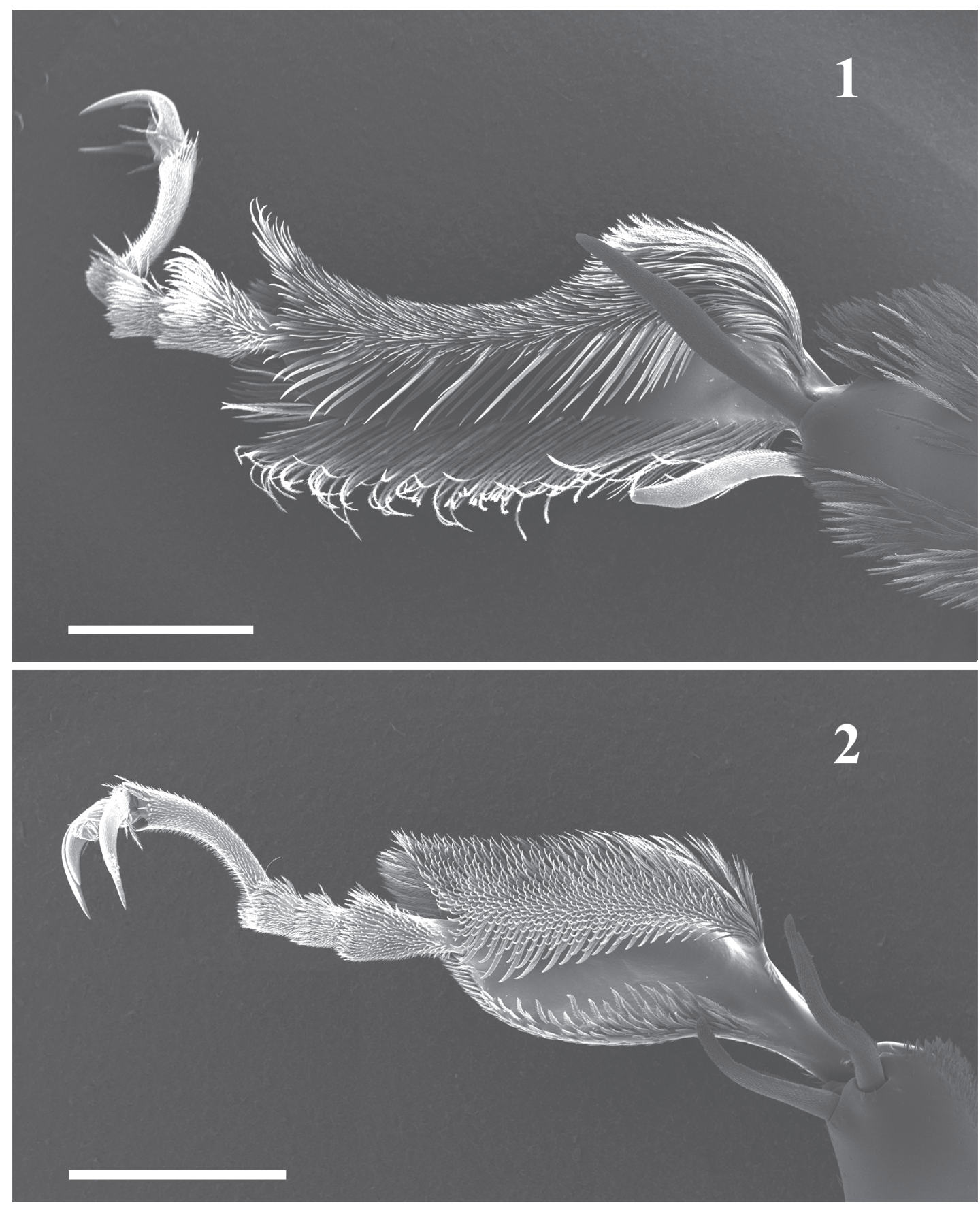

Figs. 1-2. Hind tarsus and apex of tibia of males, inner view. 1, Melitoma torquata n. sp. 2, Melitoma fulviscopis n. $s p$. Scale line, $1 \mathrm{~mm}$.

Variation. The extent of white hairs on the pronotum and the scutum is variable. In the holotype the whole pronotum and the anterior two thirds of the scutum have white hairs, forming a complete white collar. On the other extreme of variation, a male from Minas Gerais, Serra do Caraça
(UFMG), has white hairs restricted to the dorsum of the pronotum between the pronotal lobes (which bear black hairs), and the scutum bears, on the anterior third, a white patch which has the form of a triangle pointing to rear; in this specimen the hairs on the underside of the head are black. 
Biology. Michener \& Lange (1958) report and describe nests of this species, that were found near Campo Largo, in the vicinity of Curitiba, on a vertical earth bank. They recovered several pupae that matured and became adults; these specimens are now part of the type series of $M$. torquata.

Etymology. The specific name, from the Latin, means «adorned with a collar».

Material examined. Argentina. Misiones: Holotype male, Bompland, 15-II-1911, P. Jörgensen (MLP). Following paratypes: Brazil. Paraná: 1 female, Campo Largo, 27-I-1956 (DZUP); 3 males, Campo Largo, X-1955, J.S. Moure \& C.D. Michener, «ninho» (DZUP); 1 male, without procedence label, but probably also from Campo Largo (UK). São Paulo: 1 male, Campos de Jordão, $1600 \mathrm{~m}$, III-1945, Wygodzinsky (DZUP); 1 male, Capivari, Campos de Jordão, I-1961 (MSP). Minas Gerais: 1 male, Catas Altas, abelhas da zona metalurgica MG, Serra do Caraça, 9-I-1999, F.A. Silveira (UFMG).

Melitoma fulviscopis Roig-Alsina, new species (Fig. 2)

Diagnosis. This species is readily distinguished by its extensive fulvous vestiture, being the only described species of Melitoma which has reddish scopal hairs; the scopal hairs in other species are dark brown to black. It is also distinguished by the twisted hind tibial spurs and the modified hind basitasus of the male, which is petiolate basally and bears on the inner surface a longitudinal glabrous channel-like depression.

Description. Holotype male. Length 11.5 $\mathrm{mm}$; length of forewing $9.5 \mathrm{~mm}$. Color. Black, except legs reddish brown, tibial spurs yellowish brown, tegula yellowish, translucent, and alar sclerites yellowish brown. Membrane of wings slightly infuscate, not darkened apically; pterostigma and veins black.

Pubescence. Hairs whitish on clypeus, labrum, and lower part of gena; fulvous on upper half of head, pronotal lobes, scutum and scutellum, becoming paler towards lower part of mesosoma and whitish on venter of thorax. Hairs whitish on underside of front trochanter and femur; rest of legs with yellowish brown hairs. Metasomal T1 on basal vertical surface and at sides with erect pale yellowish hairs; apex of tergum bare, without hair band, except at extreme sides. T2-T5 with pale yellow apical bands, narrow on T2-T4, broad on T5; basad to the bands with short dark brown hairs. T6-T7 covered with pale yellowish hairs. Hairs on metasomal sterna pale, forming apical fringes on S2-S4, longer laterally. S6 covered with short hairs. Hairs on center of scutum 1.8-2.2 times MOD, hairs on mesopleuron longer, 2.5-3.0 times MOD. Metapostnotum close to propodeal margin with simple, short hairs 0.3 times MOD, above with short-barbed hairs 0.6-0.8 times MOD. Dark hairs on disc of T2 0.2-0.4 times MOD, pale hairs of apical band medially 0.5-0.8 times MOD, longer at sides.

Sculpture. Labrum with dense, regularly distributed punctures. Clypeus with apical impunctate rim, on lower half with punctures dense, 0.2-0.5 diameters apart, punctures sparser above, and close to upper margin nearly impunctate; interspaces shiny; epistomal suture indistinct between antennal sockets, but upper margin of clypeus recognizable due to dense punctation of supraclypeal area. Punctures on scutum and scutellum dense, 0.2-0.5 diameters apart, with shiny interspaces. Metapostnotum tessellate. Metasomal terga finely punctured.

Structure. Inner orbits nearly straight, slightly converging below, upper to lower interocular distance 1.06:1. Ocellocular distance smaller than interocellar distance $(0.85: 1)$. Distance from upper margin of midocellus to summit of head in frontal view 2.5 times MOD. Labrum rectangular, 1.2 times as wide as median length; apex truncate with median tubercle on antero-apical margin. Interantennal distance 3 times antennocular distance. First flagellomere 2.6 times longer than its apical width; proportion of lengths of scape, pedicel and proximal three flagellomeres 1.4:0.3:1:0.43:0.38. Outer hind tibial spur sinuous; inner hind tibial spur curved at a nearly $90^{\circ}$ angle. Hind basitasus petiolate basally; inner surface with longitudinal glabrous channel-like depression bordered by rows of hairs tilted over lumen of channel.

Female. Length $12.5 \mathrm{~mm}$; length of forewing $9.5 \mathrm{~mm}$. Color, pubescence and sculpture similar to those of male, except as follows. All tarsi light reddish brown. Venter of thorax and underside of coxae with fulvous, not whitish hairs. Scopal hairs on hind tibia and basitarsus, and prepygidial and pygidial fimbriae, bright fulvous. Sternal fringes on S2-S5 with long fulvous hairs. T2-T4 with apical bands of pale hairs, that on T2 interrupted medially. Hairs on head and thorax shorter, those on scutum 1.0-1.5 times MOD, on mesopleuron 1.8-2.1 times MOD. Hairs on outer surface of hind tibia 3.2-4.1 times MOD, with short retrorse barbs. Disc of clypeus more irregularly and sparsely punctate, with punctures 0.2 1.5 diameters apart; interspaces shiny. Scutellum more finely and densely punctate than scutum, 
with short narrow longitudinal impunctate streak.

Structure. Inner orbits slightly converging below, upper to lower interocular distance 1.05:1. Labrum rectangular, 1.23 times as wide as median length. Interantennal distance 2.9 times antennocular distance. Second segment of elongate labial palp 2.5 times as long as maximum eye length. First flagellomere 2.5 times longer than its apical width; proportion of lengths of scape, pedicel and proximal three flagellomeres 1.4:0.25:1:0.3:0.35.

Etymology. The specific name alludes to the color of the female scopal hairs.

Material examined. Brazil. Matto Grosso: Holotype male and two female paratypes with no further data (MACN).

Comments. The type specimens only bear an old green printed label «Matto Grosso.» These specimens belonged to the Burmeister collection and, like most of the material from Brazil in his collection, should have been collected in the mid eighteenth century. The male is partly damaged by anthrenids, having a hole on the right mesopleuron, and the right hind trochanter, the right hind femur and the right part of the S6 are partly nibbled. Both females are in perfect condition.

\section{ACKNOWLEDGMENTS}

I am indebted to the curators of the collections listed in the section Material and Methods for the loan of specimens, Jesus S. Moure and Danuncia Urban (DZUP), Charles D. Michener and Jennifer C. Thomas (KU); Fernando A. Silveira (UFMG), and Carlos Roberto F. Brandão (MSP). I thank C. D. Michener and L. A. Compagnucci for their comments on the manuscript. This study was funded by the Consejo Nacional de Investigaciones Científicas y Técnicas, Argentina, PIP 5755.

\section{BIBLIOGRAPHY}

Bullock, S. H., R. Ayala, R. Rodríguez González, R. Palacios Chávez, D Ramos Zamora, D.L. Quiroz García \& M.L. Arreguín Sánchez. 1991. Nest provision and pollen foraging in three Mexican species of solitary bees (Hymenoptera: Apoidea). PanPacific Entomol. 67: 171-176.

Linsley, E.G., J.W. MacSwain \& C.D. Michener. 1980. Nesting biology and associates of Melitoma (Hymenoptera, Anthophoridae). Univ. California Publ. Entomology 90: 1-45.

Michener, C. D. 2007. The Bees of the World. Second edition. The Johns Hopkins University Press, Baltimore and London. xvi + $953 \mathrm{pp}$.

Michener, C.D. \& R.B. Lange. 1958. Observations on the ethology of Neotropical anthophorine bees (Hymenoptera: Apoidea). Univ. Kansas Sci. Bull. 39(3): 69-96.

Roig Alsina, A. 1999. Sinopsis genérica de la tribu Emphorini, con la descripción de tres nuevos géneros (Hymenoptera, Apidae). Physis, Sec. C, Buenos Aires 56: $17-25$.

Silveira, F.A. \& J.R. Cure. 1993. High-altitude bee fauna of southeastern Brazil: implications for biogeographic patterns (Hymenoptera: Apoidea). Studies on Neotrop. Fauna and Environ. 28: 4755. 